\title{
Policy Directives for Sustainable Settlement Development at Flood Hazard Zone in Limapuluh Kota District West Sumatera Province, Indonesia
}

\author{
* Iswandi Umar \\ Department of Geography \\ Faculty of Social Science, Universitas Negeri Padang, INDONESIA \\ E_mail: iswandi_u@yahoo.com
}

*Corresponding Author, Received: January 01, 2018, Revised: March 20, 2018, Accepted: May 24, 2018

This is an open acces article distributed under the Creative Commons 4.0 Attribution License, wich permits unregtricted use, Distribution.

and reproduction in any medium provided the original work is properly cited @2017 by author and Universitas Negeri Padang

\begin{abstract}
The flood disaster has caused much harm to human life. Efforts to reduce the losses incurred by the policy directed the development of disaster-based residential areas based. The purpose of determining the direction of the policy of settlement development in the area of flood hazard in Limapuluh Kota District. To determine policy direction using AHP approach by involving 25 experts from related institutions. To determine the sustainability of development using the MDS approach. The result of policy analysis of the development of settlement area in the flood hazard area shows that there are three alternatives, namely a) disaster education; b) increased socialization in the flood hazard zone, and c) disaster-based space planning. In addition, the analysis of the sustainability of the development of residential areas shows that the institutional and legal dimensions are still low. Therefore, it is necessary to have the firmness and consistency of the government in spatial planning.
\end{abstract}

Keywords: Flood Hazard, Policy, Settlement

\section{Introduction}

Disaster hazards are geological, geological, social, cultural, political, economic, and technological conditions in an area for a certain period of time that reduce the ability to prevent, mitigate, reach preparedness and reduce the ability to respond to impacts bad danger. Efforts that can be done in order to prevent or minimize the adverse effects of the flood disaster ie: mitigation (UU Number 24/2007; Hermon, 2009; Hermon, 2012; BNPB, 2012; Hermon, 2014a). Limapuluh Kota Regency in the period 2010-2017 there was an increase of flood disasters both from the frequency of affected areas. Mitigation efforts that can be done to minimize the impact of flood risk by determining the direction of mitigation policy in the flood danger zone in Limapuluh Kota District. Limapuluh Kota District based on physical characteristics has a very dangerous area for flood disaster, among others: a) the morphology of the area about $25 \%$ is relatively flat area (0-8\%); b) about $70 \%$ of Limapuluh Kota District of primary forest area switches to secondary forest area; c) increasing rainfall intensity in upstream watershed areas (Hermon, 2014b; Hermon, 2017); and d) the development of settlement areas in the starting zone of the origin of the fluvial process (Umar and Dewata, 2017).

Floods can be defined as relatively high watercourses at the soil surface and cant be accommodated by drainage or river channels, thus transcending the river bodies and causing puddles or flows in quantities exceeding normal and causing harm to humans (BNPB 2012; Wardhono et al., 2012; Hermon, 2018a; Hermon, 2018b). According to Asdak (1995), Bechtol and Laurian (2005), that floods are influenced by three factors, 
namely meteorology, watershed characteristics, and human behaviour. Mudelsee et al., (2003), Popovska et al., (2010), Wardhono et al., (2012), Putra et al., (2013), and Umar (2016a) stated that the increase in rainfall intensity can lead to flooding, the increase of rainfall is influenced by the global temperature increase factor that impact the acceleration of the hydrological cycle. Kodoatie (2013); Umar et al., (2016b) floods can be influenced by the characteristics of watersheds (DAS) in the form of landform, elevation, soil type, and slope. In addition, Kodra and Syaurkani (2004); Personal et al., (2006); Kodoatie (2013); Yüksek et al., (2013); Hermon 2015; Hermon (2016a); Hermon (2016b); Hermon (2017); Hermon et al., (2017), states that community behaviour in land use can worsen the occurrence of floods.

\section{Method}

This research was conducted in Limapuluh Kota District, West Sumatera Province. Geographically Limapuluh Kota District is located on longitude 100015 'BT - 100053'BT and latitude 0025'LU - 0025'LS. The study took place for six months, in July - December 2017. Fig. 1 presented the administrative research location.

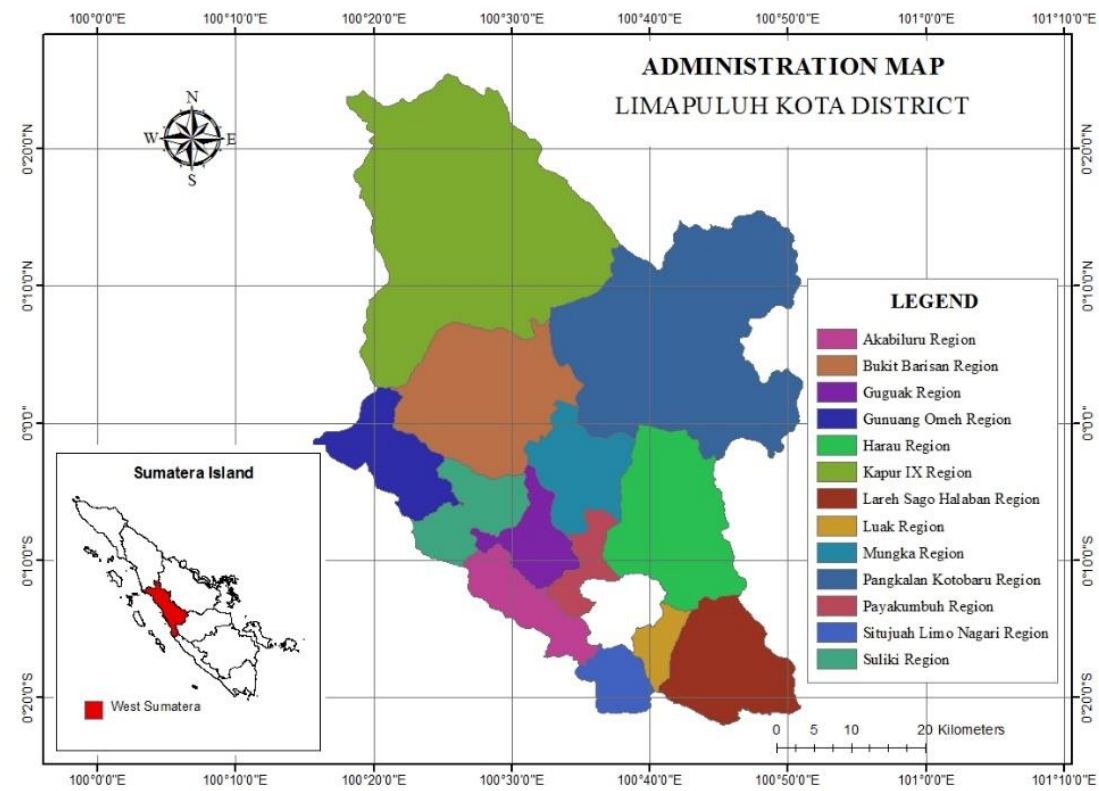

Figure 1. Administrative research location.

\section{Data analysis technique}

Mitigation policy direction is determined based on expert opinion using AHP (Analytical Hierarchy Process) method. Experts will determine scores based on a 1 to 9 scale by pairwise comparison. According to Saaty (1983), Marimin and Maghfiroh (2010) scale 1 through 9. The value and definition of expert opinions on a comparative scale are in Table 1.

Table 1. Assessment criteria in AHP

\begin{tabular}{ll}
\hline Value & Description \\
\hline 1 & A is just as important as B \\
3 & A is slightly more important than B \\
5 & A is clearly more important than B \\
7 & A is clearly more important than B \\
9 & A is absolutely more important than B \\
$2,4,6,8$ & When in doubt between two adjacent values \\
\hline
\end{tabular}

Source: Saaty (1983), Marimin and Maghfiroh (2010) 
Experts used for the determination of the direction of mitigation policy come from Universities, NGOs, BAPPEDA Limapuluh Kota District, community leaders, UNP Disaster Studies Center, and BPBD Limapuluh Kota District. The number of experts used for the determination of mitigation policy direction in flood zones is 25 experts. Furthermore, the hierarchical structure of the policy direction of the flood hazard area in Limapuluh Kota District is presented in Fig. 2.

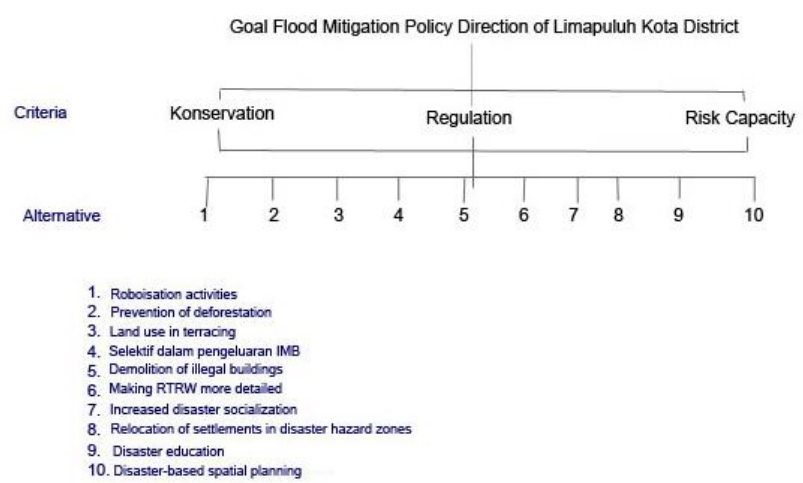

Figure 2. The hierarchy structure of the policy directives of the flood hazard settlement areas

To determine the residential area sustainability analysis in the flood hazard zone using the MDS approach. The scale used in the MDS approach is the liker scale. The value is determined based on the opinion of experts who understand the problem of settlement and flood disaster. The dimensions used in the sustainability analysis are divided into four, namely: socioeconomic, biophysical, legal, and institutional. Each of these dimensions breaks down into several sub-dimensions (Umar and Dewata, 2017).

\section{Results and Discussion}

Limapuluh Kota district has a population growth rate of $1.9 \%$ per year. According to Sadyohutomo (2008); Mutaáli (2012); Umar and Dewata (2017), that high population growth in a region will create conflicts between land use. Kaur et al., (2004), Personal et al., (2007), Putra et al., (2017), added high population growth will lead to a shift in the ecological function of space, waking space is more dominant and urges the natural space to change function. Changes in the ecological function of the space will lead to a reduction in the ability of the land to absorb water during the rainy season.

Flood disaster in Limapuluh Kota District in 2010-2017 period has increased the frequency of the occurrence and extent of areas affected by the flood disaster. The flood disaster in February 2017 has soaked about 1,000 ha of rice fields and 4,000 houses. Asdak (1995); Hermon et al., (2018a) state three main factors causing flooding in a region, namely: the high intensity of rainfall in a long time, the characteristics of watersheds, and community behaviour. The results of flood hazard analysis in Limapuluh Kota District, about $6.2 \%$ have high hazard, 54\% medium hazard, and 38,8\% are flooded safe zone. Furthermore, when compared with land use settlement area of about $27 \%$ enter in the very vulnerable category. Fig. 3 presents the flood hazard zones in Limapuluh Kota District. 


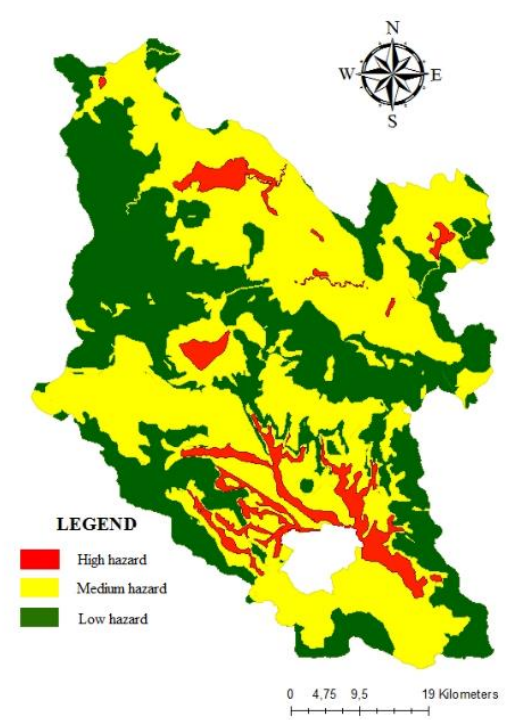

Figure 3. Zoning map of flood hazard in Limapuluh Kota District.

Limapuluh Kota District has about 6,2 percent of the high hazard zone of flooding. Therefore, it is necessary to formulate policy measures in the form of regulation, conservation, and mitigation. The results of the analysis of each of these criteria by using AHP method obtained three alternative main policy directions are: a) disaster education; b) increased socialization in flood hazard zones; and c) disaster-based space planning. Fig. 4 is presented as a result of the analysis of sustainable development policy on the flood hazard zone.

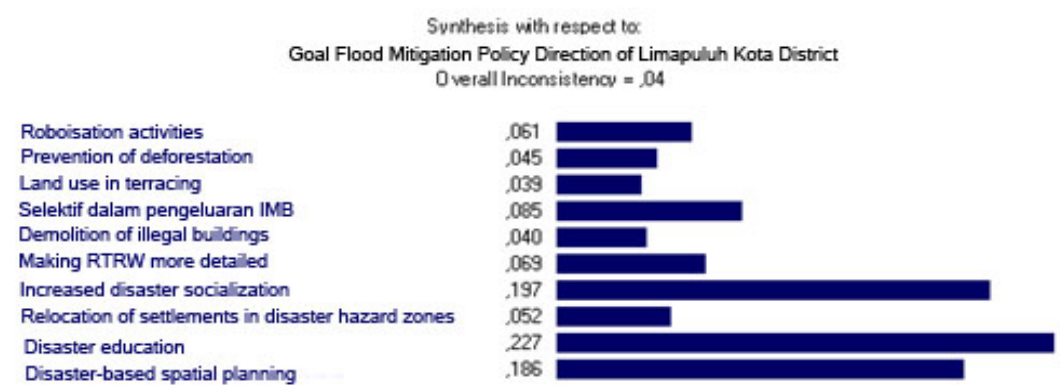

Figure 4. Policy directives of the flood hazard settlement areas.

Sustainable development is a development that utilizes natural resources optimally for the needs of the present generation without ignoring the need for future generations. In the context of sustainable development land use that a development must be a plan that takes into account all interests and without leaving environmental damage for the present generation and future generations. Evaluating land suitability and prioritizing the development of settlement areas is one form of policy directives that can be done in a sustainable manner. The description of the condition of sustainability in land use in Limapuluh Kota District is determined by the analysis of MDS (Multi-Dimensional Scaling). The dimensions of the assessment are differentiated into four categories: biophysical, socioeconomic, legal and political, and institutional. The analysis of the four dimensions shows that socioeconomic dimension is sustainable, biophysical dimensions are sustainable, and the dimensions of law and institutions are not sustainable. The results of the sustainability analysis in land use are presented in Fig. 5. 


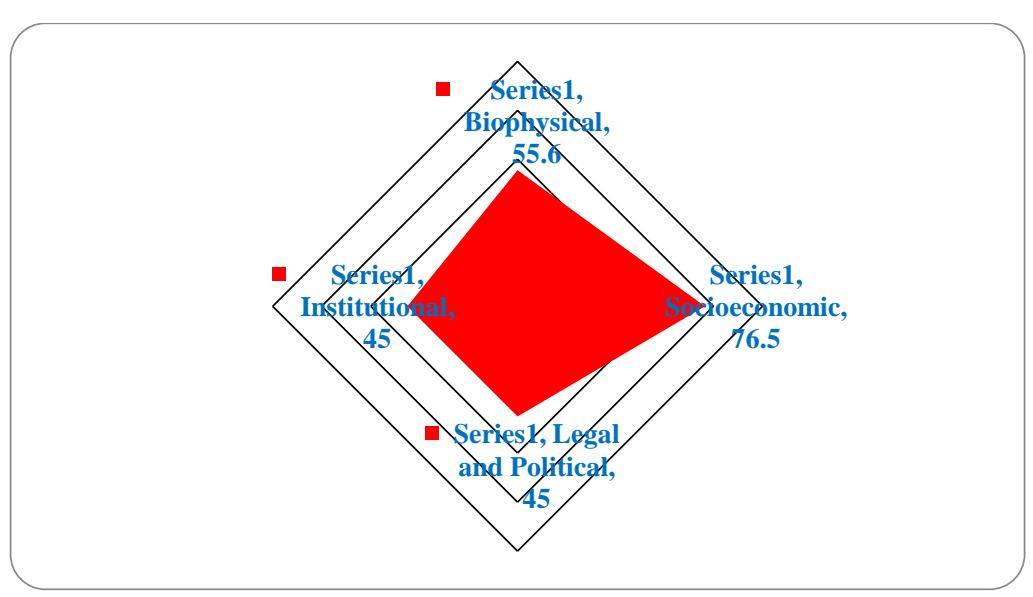

Figure 5. Sustainability analysis in land use.

\section{Conclusion}

Limapuluh Kota District has about 6,2 percent of the area with high hazard to flood. The results of the analysis of each of these criteria by using AHP method obtained three alternative main policy directions are: a) disaster education; b) increased socialization in flood hazard zones and c) disaster based space planning. The dimensions of the assessment are differentiated into four categories: biophysical, socioeconomic, legal and political, and institutional. The analysis of the four dimensions shows that socioeconomic dimension is sustainable, biophysical dimensions are sustainable, and the dimensions of law and institutions are not sustainable.

\section{References}

Asdak C. (1995). Hidrologi dan Pengelolaan Daerah Aliran Sungai. Percetakan Gadjah Mada University. Yogyakarta.

Bechtol, V and L. Laurian. (2005). Restoring Straightened Rivers for Sustainable Flood Mitigation. Disaster Prevention and Management, 14(1), pp: 6-19.

[BMKG] Badan Meteorologi Klimatologi dan Geofisika Sicincin. (2017). Data curah hujan periode 1975-2017. BMKG Sicincin. Sicincin.

[BNPB] Badan Nasional Penanggulangan Bencana. (2012). Pedoman Umum Penanggulangan Resiko Bencana. Jakarta.

[BPBD] Badan Penanggulangan Bencana Daerah Kabupaten Limapuluh Kota. (2017). Catatan Kebencanaan Daerah. BPBD Kab. Limapuluh Kota. Limapuluh Kota.

El-Kadi, A and E. Yamashita. (2007). Modeling Streamflows and Flood Delineation of the 2004 Flood Disaster. Manoa, O'ahu, hawai'i1. Pacific Science, 61(2), pp: 235-238.

Gharagozlou, A., H. Nazari., and M. Seddighi. (2011). Spatial Analysis for Flood Control by Using Environmental Modeling. Journal of Geographic Information System, 3(4), pp: 367-372.

Hermon, D. (2009). Dinamika Permukiman dan Arahan Kebijakan Pengembangan Permukiman pada Kawasan Longsor di Kota Padang. Disertasi. IPB Bogor

Hermon, D. (2012). Mitigasi Bencana Hidrometeorologi: Banjir, Longsor, Degradasi Lahan, Ekologi, Kekeringan, dan Puting Beliung. UNP Press.

Hermon, D. (2014a). Impact of Land Cover Change on Climate Change Trend in Padang, Indonesia. Indonesia Journal of Geography. Vol. 46. No. 2: 138-142.

Hermon, D. (2014b). Geografi Bencana Alam. Radjawali Press. 
Hermon, D. (2015). Estimate of Changes in Carbon Stocks on Land Cover Change in the Leuser Ecosystem Area. Forum Geografi. Indonesia Journal of Spatial and Regional Analysis. Vol. 29. Issue 2: 187-196.

Hermon, D. (2016a). The Changes of Carbon Stocks and $\mathrm{CO}_{2}$ Emission as The Result of Land Cover Change for Tin Mining and Settlement in Belitung Island Indonesia. Journal of Geography and Earth Sciences. Vol. 4: 17-30.

Hermon, D. (2016b). The Changes of Carbon Stocks and $\mathrm{CO}_{2}$ Emission as the Result of Land Cover Change for Tin Mining and Settlement in Belitung Island, Indonesia. Journal of Geography and Earth Science. Vol. 4. No. 1: 17-30.

Hermon, D., P. Iskarni., O. Oktorie., and R. Wilis. (2017). The Model of Land Cover Change into Settlement Area and Tin Mining and its Affecting Factors in Belitung Island, Indonesia. Journal of Environment and Earth Science. Vo;. 7. No. 6: 32-39.

Hermon, D. (2017). Climate Change Mitigation. Rajawali Pers (Radjagrafindo). Jakarta.

Hermon, D., A. Putra., and O. Oktorie. (2018a). Suitability Evaluation of Space Utilization Based on Enviromental Sustainability at The Coastal Area of Bungus Bay in Padang City, Indonesia. Vol. 14, Issu 41: 193-202.

Hermon, D., Ganefri., A. Putra., and O. Oktorie. (2018b). The Model of Mangrove Land Cover Change for the Estimation of Blue Carbon Stock Change in Belitung Island-Indonesia. International Journal of Applied Environmental Sciences. Vol. 13. Number 2: 191-202.

Karmakar, S., A. Simonovic, A. Peck, and J. Black. (2010). An Information System for Risk-Vulnerability Assessment to Flood. Journal of Geographic Information System, 2(3), pp: 129-146.

Kaur, E., H. Palang, and H. Soovali. (2004). Landscapes in Change-Opposing Attitudes in Saaremaa, Estonia. Landscape and Urban Planning, 67, pp: 109-120.

Kodra, H.S.A., dan Syaurkani. (2004). Bumi Makin Panas Banjir Makin Luas. Penerbit Yayasan Nuasa Cendikia. Bandung.

Kodoatie, R. (2013). Rekayasa dan Banjir Kota. Penerbit ANDI.Yogyakarta.

Kunreuther, H. (2008). Reducing Losses from Catastrophic Risks Through Long-term Insurance and Mitigation. Social Research, 75(3), pp: 905-930.

Marimin and N. Maghfiroh. (2010). Aplikasi Teknik Pengambil Keputusan Dalam Manajemen Rantai Pasok. IPB Press. Bogor.

Mudelsee, M., M. Borngen, G. Tetzlaff, and U. Grunewald. (2003). No Upward Trends in The Occurrence of Extreme Floods in Central Europe. Nature, 425(6954), pp: 1-9.

Muta'ali, L. (2012). Daya Dukung Lingkungan untuk Perencanaan Pengembangan Wilayah. Badan Penerbit Fakultas Geografi (BPFG) Universitas Gadjah Mada. Yoyakarta.

Penning-Rowsell, E. (2003). Flood Hazard Response in Argentina. Geographical Review, 86(1), pp: 72-90.

Popovska, C., M. Jovanovski, D. Ivanoski, I. Pesevski. (2010). Storm Sewer System Analysis In Urban Areas and Flood Risk Assessment. The Technical University of Civil Engineering from Bucharest.75(3), pp: 95-110.

Pribadi, D., D. Shiddiq, and M. Ermyanila. (2006). Model Perubahan Tutupan Lahan dan Faktor-Faktor yang Mempengaruhinya. Jurnal Teknologi LingkunganBPPT. 3 (1), pp: 77-91.

Putra A., S. Husrin, and Triyatno. (2013). Analisa Bencana Banjir di Kota Padang (Studi Kasus Intensitas Curah Hujan Kota Padang 1980-2009 dan Aspek Geomorfologi). Prosiding Seminar Sains Atmosfer 2013. 24-33.

Putra, A., U.J. Wisha, and Kusumah. (2017). Spatial Analysis of River Line and Land Cover Changes in Kampar River Estuary: The Influence of Tidal Bore Bono Phenomenon. Indonesian Journal of Spatial and Regional Analysis (Forum Geografi), 31(2), 220-231.

[RI] Republik Indonesia. (2007). Undang-Undang No 24 Tahun 2007 tentang Penanggulangan Bencana. Lembaran Negara RI Tahun 2007, No 68. Sekretariat Negara. Jakarta.

Stoica, A., and I. Iancu. (2011). Flood Vulnerability Assesment Based on Mathematical Modeling. The Technical University of Civil Engineering from Bucharest., 425(69), pp: 1-9. 
Suripin. (2004). Sistem Drainase Perkotaan yang Berkelanjutan. Penerbit ANDI . Yogyakarta.

Sadyohutomo, M. (2008). Manajemen Kota dan Wilayah Realitas dan Tantangan. Penerbit Bumi Aksara. Jakarta.

Umar, I. (2016a). Mitigasi Bencana Banjir pada Kawasan Permukimann Di Kota Padang (disertasi). Bogor (ID): Sekolah Pascasarjana IPB.

Umar, I., Widiatmaka, B. Pramudya, dan B. Barus. (2006b). Delineation of Flood Hazard Zones by Using a Multi-Criteria Evaluation Approach in Padang West Sumatera Indonesia. Journal of Environment and Earth Science, 4 (3), pp: 27-34.

Wardhono, A., G. Pratomo, B. Prakoso, and C. Qori'ah. (2012). Countermeasures Flood Disaster Sampean River Policy in Situbondo District. Journal of Law and Social Sciences (JLSS), 2(1), pp: 118-122.

Yang, M., X. Qian, Y. Zhang, J. Sheng, D. Shen, and Y. Ge. (2011). Spatial Multicriteria Decision Analysis of Flood Risks in Aging-Dam Management in China. International Journal of Environmental Research and Public Health, 8(5), pp: 1368-1387.

Yüksek, O., M. Kankal, and O. Üçüncü. (2013). Assessment of Big Floods in the Eastern Black Sea Basin of Turkey. Environmental Monitoring and Assessment, 185(1), pp: 797-814. 